J. Dairy Sci. 97:2219-2225

http://dx.doi.org/10.3168/jds.2013-7268

(C) American Dairy Science Association ${ }^{\circledR}, 2014$.

\title{
Short communication: Effects of systemic treatment with penethamate hydriodide on udder health and milk yields in dry primiparous Mediterranean buffaloes (Bubalus bubalis)
}

\author{
J. Guccione, ${ }^{11}$ A. Pesce,† M. Pascale,‡ N. Tommasini,§ F. Garofalo,† A. Di Loria,\# L. Cortese, ${ }^{\star}$ C. Salzano,† \\ and P. Ciaramella* \\ *Department of Veterinary Medicine and Animal Production, University of Napoli "Federico II," Via Delpino 1, 80137 Napoli, Italy \\ †Istituto Zooprofilattico del Mezzogiorno, Via A. Jervolino 19, 81100 Tuoro, Caserta District, Italy \\ $¥$ Veterinary practitioner, 81100 Caserta, Italy \\ §Boehringer Ingelheim Italia, Via Lorenzini 8, 20139 Milano, Italy \\ \#Department of Health Science, University of Magna Graecia of Catanzaro, 88100 Catanzaro, Italy
}

\section{ABSTRACT}

The effects of penethamate hydriodide (Mamyzin, Boehringer Ingelheim, Ingelheim, Germany) on udder health and milk yields were evaluated in primiparous Mediterranean buffaloes (Bubalus bubalis). An intramuscular administration of 10 million international units was performed in 20 buffaloes at $7 \mathrm{~d}$ precalving (treatment group; TG), and 20 animals were enrolled as the control group (CG). Evening milk samplings were performed at 10, 30, and $60 \mathrm{~d}$ in milk (DIM). Somatic cell count (SCC) values were evaluated on composite milk samples, whereas bacteriological culture and California Mastitis Test were performed on quarter milk. Daily milk yields were recorded after all milkings. After 60 DIM, composite milk samples from each animal were collected for monthly SCC and bacteriological culture until drying off. Statistically significant differences were found between the prevalence of mastitic quarters in the 2 groups at 10 and 30 DIM, and between the incidence of mastitic animals during the examined period (TG: 4/20, $20 \%$ vs. CG: 10/20, 50\%). Even though lower and higher values of SCC and milk yields were found in TG during each sampling, statistically significant differences were only found at 30 (SCC) and 60 DIM (milk yields). In our study, the antibiotic administration precalving showed good bactericidal activity against the most common udder-specific pathogens that cause mastitis in primiparous Mediterranean buffaloes, and greater efficacy was observed at 10 and 30 DIM compared with 60 DIM. Given the significant decrease in SCC and increase in yields achieved, use of this antibiotic could be economically beneficial in buffalo breeding.

Received July 18, 2013.

Accepted January 6, 2014.

${ }^{1}$ Corresponding author: jacopo.guccione@unina.it
Key words: Mediterranean buffalo, penethamate hydriodide, mastitis, antibiotics

\section{Short Communication}

In Mediterranean buffalo, as in cow, mastitis is mainly caused by bacteria (Galiero, 2002). Several contagious (Staphylococcus aureus, Streptococcus agalactiae), environmental (Streptococcus uberis and Streptococcus dysgalactiae, Escherichia coli, Enterobacteriaceae, and yeasts), and opportunistic (CNS) species have been recognized as causing mastitis in these ruminants (Moroni et al., 2006; Fagiolo and Lai, 2007), during the first 2 mo of milking and in primiparous animals (19.4 and $43.6 \%$, respectively; Dhakal et al., 2008). Beginning lactation with a low prevalence of IMI is an important prerequisite to ensure optimal milk production and udder health throughout lactation (Green et al., 2008). A relationship between infections that occur, or that are not cured, during the dry period and resulting clinical mastitis or increased SCC in early lactation is widely described in dairy cattle, and the dry (nonlactating) period is now recognized as a critical time for the control of clinical and subclinical mastitis (Green et al., 2008). At present, no data about this relationship are present in Mediterranean buffaloes. In recent years, research has focused on precalving antibiotic treatment of dairy heifers (Bryan and Friton, 2005; Roy et al., 2005; Borm et al., 2006). Although recent evaluations of the effectiveness of dry cow antibiotic treatment have confirmed significant value in preventing new infections during the dry period and at calving (Hassan et al., 1999; Berry and Hillerton, 2002; Huxley et al., 2002), concerns have been raised that blanket administration of dry cow therapy is indiscriminate and results in overuse of antibiotics, as a proportion of the cows will be uninfected at drying off. The World Health Organization has issued recommendations on reducing the use 
of antibiotics (WHO, 1998), and organic or biological farming prohibits the routine use of dry cow therapy. At present, no specific antibiotics registered for dairy Mediterranean buffaloes are manufactured, so the administration of antibiotics ad hoc created for cows to reduce persistent infections and mastitis postcalving is a common practice in nonlactating primiparous buffaloes. Only throughout scientific evaluation of the properties and effects of the used antibiotics can selective and appropriate measures of their use be suggested in these ruminants. Considering the evidence, the aim of the current study was to evaluate the effectiveness of treating dry, primiparous Mediterranean buffaloes with penethamate hydriodide to prevent periparturient mastitis and IMI, improve milk quality and yields, and quantify the possible economic benefit resulting from its use.

An intramuscular administration of 10 million IU of penethamate hydriodide (Mamyzin, Boehringer Ingelheim, Ingelheim, Germany; $30 \mathrm{~mL}$ ) was administered in 20 healthy primiparous buffaloes (treatment group; TG) 7 d precalving, whereas 20 buffaloes were left untreated and enrolled as the control group $(\mathbf{C G})$. All the animals, randomly chosen between December 2011 and February 2012, were reared in a breeding herd of 600 buffaloes located in southern Italy. A complete clinical udder examination was performed in each animal and those with traumatic evidence of mastitis or other udder problems were excluded. The primiparous buffaloes were separated from lactating buffaloes before parturition and no concomitant therapies around calving were conducted. All animals enrolled were milked before the rest of herd, and samples were collected immediately before the regular milking time as described by Baumgartner (2005) for cows. At 10, 30, and 60 DIM, a composite milk sample of $50 \mathrm{~mL}$ was collected from each animal and placed in a sterile test-tube (Nuova Aptaca, Canelli Asti, Italy) during evening milking to perform SCC. Another sterile 10-mL tube (BD Vacutainer, Becton, Dickinson and Co., Oxford, UK) was used for the quarter bacteriological milk culture (BC). The California Mastitis Test (CMT) was also performed on quarter milk, and daily milk yields were always recorded after milking using automatic dedicated software (Afifarm, Afimilk, Kibbutz Afikim, Israel). After 60 DIM, daily milk yields and SCC values were detected monthly until d 260 (dryoff). All samples were collected aseptically according to National Mastitis Council (2004) guidelines. A great variability in drying-off time was detected, between 240 and 260 DIM in the animals enrolled, so the last sample considered useful for economic and statistical analysis was that collected at 240 DIM. All samples were cooled in a cool box $\left(4^{\circ} \mathrm{C}\right)$ and brought to the reference labora- tory within $1 \mathrm{~h}$. Each sample was submitted to SCC and $\mathrm{BC}$ within $2 \mathrm{~h}$ after collection; SCC was determined using a Fossomatic 5000 (Foss Electric, Hillerød, Denmark). The BC and identification of bacteria were performed according National Mastitis Council (1999) methods, including colony morphology, catalase test, Gram stain, further biochemical properties, Christie, Atkinson, Munch-Peterson (CAMP) test, and detection of hemolysis. According to Kreiger et al. (2007), when 3 or more dissimilar colony types were isolated on the plate, the sample was considered contaminated. Final identification of microorganisms was performed using a colorimetric automated identification system (Vitek 2 XL 120; bioMérieux Inc., Hazelwood, MO) according to the manufacturer's instructions. Isolates identified with confidence levels $>0.90$ were considered identified at the species level; otherwise, they were identified at the genus level. All animals enrolled were individually submitted to complete clinical examination with particular care for the udder. Complete hemato-biochemical analyses were also performed to confirm health status. Local and systemic reactions and changes in milk appearance were observed and recorded during each sampling. Buffaloes that showed macroscopic abnormalities in milk were individually submitted to clinical examination, and new hemato-biochemical analyses were performed. The quarters included were defined as healthy, affected by IMI, or affected by mastitis according to SCC values, microbiological status, and presence of clinical signs, as indicated in Table 1, and according to several studies (Moroni et al., 2006; Fagiolo and Lai, 2007; Tripaldi et al., 2010). Briefly, each mammary quarter was considered affected by IMI (positive $\mathrm{BC}$ to udder-specific bacteria, SCC $<200 \times 10^{3}$ cells/ $\mathrm{mL}$ ) if the same pathogen was isolated in 2 consecutive samples (Berry and Hillerton, 2002). Mastitis quarters were those showing an inflammatory status characterized by SCC above the threshold of $200 \times 10^{3}$, BC positive, with (clinical mastitis) or without (subclinical mastitis) clinical signs (Table 1). All quarters affected by mastitis were excluded from the study (end-point phase). A complete udder ultrasonography examination (teat and gland) was performed in mastitic animals, using a 12-MHz linear probe (General Electrics, Logiq E, Milan, Italy). The teats were dipped in warm water to improve image quality, as described for cows by Sendag and Dinc (1999).

According to Oliver at al. (2003), a partial budgeting method was used to estimate the net revenue increase for the antibiotic-treated group. This economic analysis method only accounted for revenues and costs that changed from one management to another; variable costs such as feed consumption were not included. An average of per-animal daily milk yield was calculated 
Table 1. Definitions of quarter health status in the study

\begin{tabular}{lcll}
\hline $\begin{array}{l}\text { Quarter } \\
\text { health status }\end{array}$ & SCC & & Clinical signs \\
\hline Healthy & $\leq 200$ & Negative or positive to non-udder-specific pathogens & Negative \\
IMI & $\leq 200$ & Positive to udder-specific pathogens & Negative \\
Mastitic & $>200$ & Positive to udder-specific pathogens & Absence (subclinical); Presence (clinical) \\
\hline
\end{tabular}

for both groups using the overall monthly milk yields. An average buffalo milk price of $\$ 1.44 / \mathrm{L}$ was used for the economic analysis. Considering the antibiotic's time of administration ( $7 \mathrm{~d}$ precalving) and the withholding period indicated by label instruction of the products for milking $(6 \mathrm{~d})$, no losses due to withholding milk for antibiotic residues were included in the economic analysis. The economic benefit was calculated using the following modified formula suggested by Kreiger et al. (2007):

$$
N R=\{p \times[(D M Y T-D M Y C) \times 240 \mathrm{~d}]\}-C^{T},
$$

where $N R$ is the net revenue change from treatment, $p$ is the price of milk, $D M Y T-D M Y C$ is the difference in daily mean milk yield for animals of TG and CG, respectively, $240 \mathrm{~d}$ indicates days of lactation, and $C^{T}$ is the cost of the treatment. The mean treatment cost of $\$ 35.48$ per buffalo under current conditions included antibiotics, syringes, and needles, and partial veterinary consulting costs were included. The overall price was based on mean Italian standards and could be different in other countries.

Different health status of animals and quarters, SCC, and milk yields were analyzed by standard descriptive statistics, and normality was assessed using histograms, normal probability (QQ) plots, and Shapiro-Wilk test. Data were expressed as absolute numbers, percentage, and mean \pm SD. Somatic cell counts were expressed as $\log _{10}$ (cells $\left./ \mathrm{mL}\right)$. Untransformed and log-transformed variables were compared using parametric test $\left(\chi^{2}\right.$ test and Student's $t$-test); $P$-values $<0.05$ were considered significant. All statistical data were analyzed using SPSS software (version 17.0, SPSS Inc., Chicago, IL).

During the whole study, $720 \mathrm{BC}$ and CMT on quarter milk samples and 360 determinations of SCC on composite milk samples and milk yields were also recorded. The prevalence of healthy quarters (negative $\mathrm{BC}, \mathrm{SCC}<200 \times 10^{3}$ cells $\left./ \mathrm{mL}\right)$ was $73.8 \%(59 / 80)$, $40.3 \%(29 / 72)$, and $36.8 \%(25 / 68)$ at 10,30 and 60 DIM in TG, and $66.3 \%(53 / 80), 26.8 \%(15 / 56)$, and $27.3 \%(12 / 44)$ at 10,30 and 60 DIM, respectively, in CG. During the same 3 samplings, the prevalence of quarters affected by IMI (BC positive for udder-specific bacteria, SCC $<200 \times 10^{3}$ cells $\left./ \mathrm{mL}\right)$ was $23.8 \%(19 / 80)$, $58.3 \%(42 / 72)$, and $64.8 \%(42 / 68)$ in TG, and $18.8 \%$
$(15 / 80), 62.5 \%(35 / 56)$, and $68.2 \%(30 / 44)$ in the CG, respectively. All udder-specific bacteria isolated during the first 60 DIM with their relative prevalence are summarized in Table 2. Finally, the prevalence of mastitic quarters (BC positive for udder-specific bacteria, with SCC $>200 \times 10^{3}$ cells $\left./ \mathrm{mL}\right)$ was $2.5 \%(2 / 80), 1.4 \%$ $(1 / 72)$, and $1.5 \%(1 / 68)$ in TG, and $15 \%(12 / 80), 10.7 \%$ $(5 / 56)$, and $4.6 \%(2 / 44)$ in CG, respectively. Statistically significant differences between the 2 groups were found at $10(P=0.005)$ and $30(P<0.05)$ DIM (Figure 1). Overall appearance of depression; udder swelling and pain; off-color and watery appearance of milk; and presence of flakes, clots, and pus were recorded during the clinical examination in mastitic quarters. A slight neutrophilia (data not shown) and obvious ultrasonography abnormalities were found in all mastitic buffaloes examined. During the first 60 DIM, a statistically significant difference in the incidence of mastitic animals between TG $(20.0 \% ; 4 / 20)$ and CG $(50.0 \% ; 10 / 20)$ was detected $(P<0.05$; Figure 2$)$. The $\log _{10}$ SCC values detected during the whole lactation are reported in Table 3; a statistically significant difference was found between mean values of SCC in TG $\left(4.89 \pm 5.05 \log _{10}\right.$ cells $/ \mathrm{mL} \pm \mathrm{SD})$ and $\mathrm{CG}\left(5.16 \pm 5.21 \log _{10}\right.$ cells $/ \mathrm{mL} \pm$ $\mathrm{SD})$ at $30 \mathrm{DIM}(P<0.05$; Table 3$)$. Considering the whole lactation period, the mean $\log _{10} \mathrm{SSC}$ values were $5.36 \pm 5.24 \log _{10}$ cells $/ \mathrm{mL}$ in TG and $5.41 \pm 5.20 \log _{10}$ cells/mL in CG. The milk yields in each group at sampling time are shown in Table 3. At drying-off, the total milk yields over the whole lactation were $1,779 \mathrm{~L}$ and 1,659.4 L in TG and CG, respectively; a statistically significant difference was found in mean milk yields per animal between the 2 groups (TG: $12.78 \mathrm{~L} / \mathrm{d}$ and CG: $10.27 \mathrm{~L} / \mathrm{d})$ at $60 \mathrm{DIM}(P<0.05$; Table 3$)$. During the samplings at 10,30 , and $60 \mathrm{DIM}$, the percentages of quarters negative by CMT were $76.2 \%(61 / 80), 90.2 \%$ $(65 / 72)$, and $22.0 \%$ (15/68) for TG, and $60.0 \%$ (48/80), $66.0 \%(35 / 56)$, and $29.5 \%$ (13/44) for CG. In each animal, hemato-biochemical analyses were negative except in mastitic buffalo, in which leukocytosis was always found (data not shown).

Finally, the economic analysis showed a mean peranimal milk yield of 9.88 and $9.22 \mathrm{~L} / \mathrm{d}$ in TG and CG, respectively. A daily mean increase of $0.66 \mathrm{~L} /$ animal was observed in TG. Multiplying the latter by $240 \mathrm{~d}$, the mean increase in milk yield was $159.33 \mathrm{~L} /$ animal 


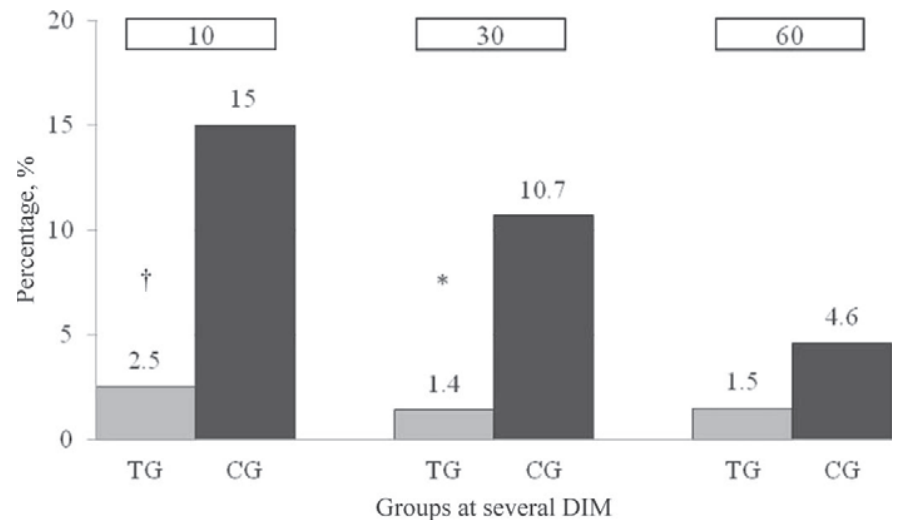

Figure 1. Prevalence of mastitic quarters at 10, 30, and 60 DIM; TG and $\mathrm{CG}=$ treated group and control group, respectively. Statistically significant differences were found between the 2 groups at $10(\dagger P=0.005)$ and $30(* P<0.05)$ DIM.

and per lactation. Multiplying this value by the actual mean buffalo milk price of $\$ 1.44 / \mathrm{L}$ resulted in a mean increase in gross revenue of $\$ 229.43$ per animal. Subtracting the mean cost of treatment of $\$ 35.48$ per animal, the mean overall return on investment was $\$ 193.95$ per buffalo treated.

The aims of the study were to verify the effects of penethamate hydriodide (diethylaminoethyl ester of penicillin, Mamyzin) in the short term (percentage of IMI and mastitis, SCC and milk yield during the first 60 DIM) and long term (SCC and yield values until drying-off). Under our experimental conditions, the antibiotic was administered once at $7 \mathrm{~d}$ precalving with the aim of observing its bactericidal features during the periparturient period against staphylococci and streptococci (Staph. aureus, CNS, Strep. uberis, Strep. agalactiae, and Strep. dysgalactiae). Penethamate hydriodide is a pre-drug of penicillin $G$ that accumulates in high levels in both mastitic and normal milk due to its pharmacokinetic profile and "ion trapping" phenomenon (Rasmussen, 1959; Ziv, 1980). Considering that a 5 -d withholding period for milk after the last treatment was considered according to label instructions of the products, its use for $7 \mathrm{~d}$ precalving with a one-time

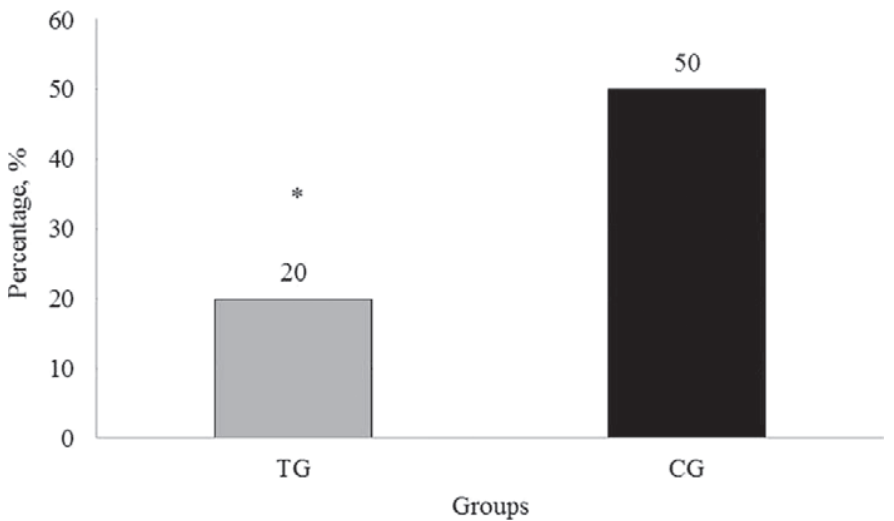

Figure 2. Incidence of mastitic buffaloes during the first $60 \mathrm{DIM}$; TG and CG = treated group and control group, respectively. A statistically significant difference was found between the 2 groups: ${ }^{*} P<$ $0.05)$.

administration allowed us to avoid losses due to withholding milk because of antibiotic residues. A preventive treatment at the end of the nonlactating period reduces the risk due to presence of antibiotic residues in colostrum and possible resistance of gut bacteria to antibiotic increase (Langford et al., 2003). Furthermore, according to Kreiger et al. (2007), the advantages of intramuscular treatment included reduced risk of injury to operators while working with primiparous animals not usually used to handling; reduced risk of damage to the teat canal; no risk of accidental introduction of new mammary gland infections; and no additional facilities required for restraint of primiparous animals. A good bactericidal action against periparturient invading bacteria, when the antibiotic is administered during the end of nonlactating period, was supposed by the authors, considering the significant increase of mastitic quarters recorded at $10(P=0.005)$ and $30(P$ $<0.05)$ DIM in CG (Figure 1) and the higher incidence of mastitic buffaloes (CG: $50 \%$ vs. TG: $20 \%$ ) observed after 60 DIM (Figure 2; $P<0.05$ ). Our results show that treated animals were more resistant to developing mastitis at the end of lactation and shortly postcalving (Figure 1), as observed in analogous studies performed

Table 2. Prevalence (\%) of udder-specific pathogens isolated in treated and control groups at several DIM

\begin{tabular}{|c|c|c|c|c|c|c|}
\hline \multirow[b]{2}{*}{ Bacteria } & \multicolumn{2}{|c|}{10 DIM } & \multicolumn{2}{|c|}{30 DIM } & \multicolumn{2}{|c|}{60 DIM } \\
\hline & Treated & Control & Treated & Control & Treated & Control \\
\hline Aerococcus viridans & 5 & 5 & 5.6 & 12.5 & 12.5 & 12.9 \\
\hline Staphylococcus aureus & - & 5 & 50 & 39.3 & 48.9 & 45.4 \\
\hline Staphylococcus chromogenes & 15 & 17.5 & 5.6 & - & - & 5.6 \\
\hline Streptococcus dysgalactiae & 5 & 5 & 27.8 & - & - & - \\
\hline Staphylococcus haemolyticus & 12.5 & 27.5 & 9.7 & 21.4 & 21.9 & 2.3 \\
\hline Staphylococcus xylosus & 4.5 & 7.5 & - & 3.6 & - & - \\
\hline Staphylococcus warneri & 2.5 & 10 & 2.7 & 3.6 & - & - \\
\hline
\end{tabular}


in cow heifers (Kreiger et al., 2007). A slightly lower prevalence of IMI was found in TG than in CG at 30 and 60 DIM. According to studies performed in cow heifers, even though different routes of administration were used, IMI were less severe and showed a higher rate of higher spontaneous cure in the antibiotic-treated group than in the control group, where IMI were more severe, required treatment, and had a higher probability of progressing to chronic and recurrent infection (Bryan and Friton, 2005; Borm et al., 2006; Kreiger et al., 2007). The nonlactating period can be considered a key period for the acquisition and elimination of bacteria that cause IMI (Todhunter et al., 1991; Bradley and Green, 2000; Green et al., 2002). Several studies have shown the prevalence of staphylococci in milk samples of nonlactating cow heifers to be up to $37 \%$ (Oliver et al., 2004; Roy et al., 2005; Borm et al., 2006). Kreiger et al. (2007), even though using different plans of administration, showed no Staph. aureus IMI at $7 \mathrm{~d}$ postcalving in cow heifers. Similar results were detected in the present study because no animals in TG showed IMI due to the microorganism at 10 DIM (Table 2). All primiparous buffaloes ( $\mathrm{TG}$ and $\mathrm{CG}$ ) shared the same environment and had the same likelihood of exposure to potential pathogens, thus penethamate hydriodide seemed to have bactericidal properties against Staph. aureus. This result was not confirmed at 30 and 60 DIM. Milking management and hygiene, udder hygiene and bedding, poorly balanced diets, and uncontrolled sources of environmental stress can influence the development of new infections (Reinecke et al., 2006; Dufour and Dohoo, 2013) and displace a beneficial effect of any treatment administered before or at parturition (Kreiger et al., 2007).

In regard to SCC, the higher prevalence of mastitic quarters at $10(P=0.005)$ and $30 \operatorname{DIM}(P<0.05)$ and the incidence of mastitic animals $(P<0.05)$ recorded in TG contributed to a significant increase of SCC values at 30 DIM $(P<0.05$; Table 3$)$. In the current study, as also reported in in cow heifers (Reinecke et al., 2006), animals with periparturient mastitis showed higher mean SCC values during the subsequent lactation period . Furthermore, a slight increase in mean milk yields in treated nonlactating primiparous buffaloes was recorded throughout lactation (Table 3). A similar trend was confirmed in cow heifers after analogous treatment with penethamate hydriodide at the end of nonlactating period (Oliver et al., 2003; Bryan and Friton, 2005; Roy et al., 2005). No severe mastitis cases around parturition and generally milder forms of mastitis in treated groups may lead to healthier udders and better milking performance (Kreiger et al., 2007). In dairy Mediterranean buffalo, mastitis with SCC above the threshold of $200 \times 10^{3}$ cells $/ \mathrm{mL}$ is associated with 
significantly decreased milk yield and poor milk quality because of changes in the composition and coagulating properties of the milk (Tripaldi et al. 2010).

Finally, in regard to the economic analysis, a mean net benefit of $\$ 193.95 /$ buffalo from the extra milk produced was recorded in the current study, confirming similar results reported in several cow studies (Oliver et al., 2003; Bryan and Friton, 2005; Kreiger et al., 2007). During the economic analysis, the price of buffalo milk and no losses due to withholding milk after treatment contributed to the increase in net revenue.. Routine administration of penethamate hydriodide can be economically beneficial for the farmer when evaluating both the high prevalence of IMI due to grampositive bacteria leading to mastitis, recently described in Mediterranean buffaloes (Locatelli et al., 2013) and the increased milk yields detected in the TG of the present study. .

To our knowledge, this is the first report evaluating the effects of systemic antibiotic dry treatment on udder health and milk yields in primiparous Mediterranean dairy buffaloes. Even though our study included only a small number of animals, administration of penethamate hydriodide precalving showed good bactericidal properties against the most common pathogens. Greater efficacy was observed at 10 and 30 DIM than at 60 DIM. Furthermore, the effects on SCC and milk yields suggest that the antibiotic could also improve quality and yields of buffalo milk. Even though the World Health Organization (WHO, 1998) has issued recommendations on reducing the use of antibiotics during the dry period, use of penethamate hydriodide as a selective treatment could be suggested for herd health management because of the high prevalence of IMI caused by gram-positive bacteria in primiparous, nonlactating Mediterranean dairy buffaloes.

\section{ACKNOWLEDGMENTS}

The study was funded by Boehringer Ingelheim (Milan, Italy).

\section{REFERENCES}

Baumgartner, W. 2005. Guidelines for Clinical Examination of Internal and Skin Diseases in Domestic and Pet Animals. 6th ed. Parey Verlag, Stuttgart, Germany.

Berry, E. A., and J. E. Hillerton. 2002. The effect of selective dry cow treatment on new intramammary infections. J. Dairy Sci. 85:112-121.

Borm, A. A., L. K. Fox, K. E. Leslie, J. S. Hogan, S. M. Andrew, K. M. Moyes, S. P. Oliver, Y. H. Schukken, D. D. Hancock, C. T. Gaskins, W. E. Owens, and C. Norman. 2006. Effects of prepartum intramammary antibiotic therapy on udder health, milk production, and reproductive performance in dairy heifers. J. Dairy Sci. 89:2090-2098.
Bradley, A. J., and M. J. Green. 2000. A study of the incidence and significance of intramammary enterobacterial infections acquired during the dry period. J. Dairy Sci. 83:1957-1965.

Bryan, M. A., and G. M. Friton. 2005. Stochastic economic modeling of the use of penethamate hydriodide (Mamyzin ${ }^{\circledR}$ ). Pages 232-234 in Proc. Mastitis in Dairy Production: Current Knowledge and Future Solutions, Maastricht, the Netherlands. Wageningen Academic Publishers, Wageningen, the Netherlands.

Dhakal, I. P., M. Neupane, and H. Nagahata. 2008. Evaluation of direct and indirect measures of quarter milk from crossbred buffaloes. Anim. Sci. J. 79:628-633.

Dufour, S., and I. R. Dohoo. 2013. Short communication: Infection incidence and elimination rate during the dry period. J. Dairy Sci. 96:1672-1676.

Fagiolo, A., and O. Lai. 2007. Mastitis in buffalo. Ital. J. Anim. Sci. 6:200-206

Galiero, G. 2002. The control of environmental mastitis. Bubalus bubalis 1:26-28.

Green, M., J. Huxley, A. Madouasse, W. Browne, G. Medley, A. Bradley, A. Biggs, J. Breen, M. Burnell, A. Hayton, J. Husband, J. Reader, J. Statham, and M. Thorne. 2008. Making good decisions on dry cow management to improve udder health - Synthesizing evidence in a Bayesian framework. Cattle Pract. 16:200-208.

Green, M. J., L. E. Green, G. F. Medley, Y. H. Schukken, and A. J. Bradley. 2002. Influence of dry period bacterial intramammary infection on clinical mastitis in dairy cows. J. Dairy Sci. 85:25892599.

Hassan, Z., R. C. Daniel, D. O'Boyle, and A. J. Frost. 1999. Effects of dry cow intramammary therapy on quarter infections in the dry period. Vet. Rec. 145:635-639.

Huxley, J. N., M. J. Greent, L. E. Green, and A. J. Bradley. 2002. Evaluation of the efficacy of an internal teat sealer during the dry period. J. Dairy Sci. 85:551-561.

Kreiger, M., G. M. Friton, J. Hofer, K. Fuchs, and P. Winter. 2007. Effects of periparturient systemic treatment with penethamate hydriodide on udder health and milk yield of dairy heifers. J. Dairy Res. 74:392-398.

Langford, F. M., D. M. Weary, and L. Fisher. 2003. Antibiotic resistance in gut bacteria from dairy calves: A dose response to the level of antibiotics fed in milk. J. Dairy Sci. 86:3963-3966.

Locatelli, C., S. Piepers, S. De Vliegher, A. Barberio, K. Supré, L. Scaccabarozzi, G. Pisoni, V. Bronzo, F. Haesebrouk, and P. Moroni. 2013. Effect on quarter milk somatic cell count and antimicrobial susceptibility of Staphylococcus rostri causing intramammary infection in dairy water buffaloes. J. Dairy Sci. 96:3799-3805.

Moroni, P., C. S. Rossi, G. Pisoni, V. Bronzo, B. Castiglioni, and P. J. Boettcher. 2006. Relationships between somatic cell count and intramammary infection in buffaloes. J. Dairy Sci. 89:998-1003.

National Mastitis Council. 1999. Laboratory Handbook on Bovine Mastitis. Rev. ed. National Mastitis Council Inc., Madison, WI.

National Mastitis Council. 2004. Procedures for collecting milk samples in microbiological procedures for the diagnosis of bovine udder infection and determination of milk quality. National Mastitis Council Inc., Madison, WI.

Oliver, S. P., B. E. Gillespie, S. J. Ivey, M. J. Lewis, D. L. Johnson, K. C. Lamar, H. Moorehead, H. H. Dowlen, S. T. Chester, and J. W. Hallberg. 2004. Influence of prepartum pirlimycin hydrochloride or penicillin-novobiocin therapy in mastitis in heifers during early lactation. J. Dairy Sci. 87:1727-1731.

Oliver, S. P., M. J. Lewis, B. E. Gillespie, H. H. Dowlen, E. C. Jaenicke, and R. K. Roberts. 2003. Prepartum antibiotic treatment of heifers: Milk production, milk quality, and economic benefit. J. Dairy Sci. 86:1187-1193.

Rasmussen, F. 1959. Mammary excretion of benzyl penicillin, erythromycin and penethamate hydriodide. Acta Pharmacol. Toxicol. (Copenh.) 16:194-200.

Reinecke, A., I. Hansen, B. A. Tenhagen, and W. Heuwieser. 2006. Clinical mastitis and production parameters during the first lactation of primiparous cows. Sloven. Vet. Res. 43:19-22.

Roy, J. P., D. Du Tremblay, L. DesCôteaux, S. Messier, and E. Bouchard. 2005. Efficacy of intramammary pirlimycin as a pre- 
calving treatment for nulliparous heifers. Pages 956-957 in Proc. 4th IDF International Mastitis Conf., Maastricht, the Netherlands.

Sendag, S., and D. A. Dinc. 1999. Ultrasonography of the bovine udder. Turk. J. Vet. Anim. Sci. 23:545-552.

Todhunter, D. A., K. L. Smith, J. S. Hogan, and P. S. Schoenberger. 1991. Gram-negative bacterial infections of the mammary gland in cows. Am. J. Vet. Res. 52:184-188.
Tripaldi, C., G. Paolacci, M. Mairelli, M. Catta, S. Orlandini, S. Amatiste, R. Di Bernardini, and G. Catillo. 2010. Effects of mastitis on buffalo milk quality. Asian-australas. J. Anim. Sci. 23:1319-1324.

WHO (World Health Organization). 1998. The Medical Impact of Antimicrobial Use in Food Animals. WHO, Geneva, Switzerland.

Ziv, G. 1980. Drug section and use in mastitis - Systemic versus local therapy. J. Am. Vet. Med. Assoc. 176:1109-1115. 